\title{
PENERAPAN AUTHENTIC ASSESSMENT BERBASIS E-LEARNING DALAM PEMBELAJARAN BIOLOGI
}

\author{
Ida Bagus Ari Arjaya \\ Universitas Mahasaraswati Denpasar \\ email:ariarjayaunmas@gmail.com
}

\begin{abstract}
ABSTRAK
Digital literacy menempati isu terkini dalam sistem pendidikan di abad 21. Persaingan global mengakibatkan setiap siswa harus mampu mengelola dan mencari sumber informasi dengan baik Digital literacy sendiri diartikan sebagai kompetensi yang digunakan oleh peserta didik untuk berpartisipasi secara penuh dalam proses belajar dengan melibatkan pengetahuan, keterampilan, dan sikap yang efektif di dalam pemanfaatan perangkat digital. Lebih lanjut, Unesco (2017) menetapkan digital literacy sebagai salah satu life skill mendukung pendidikan sepanjang hayat, cross national curriculum, meningkatkan partisipasi pebelajar, dan meningkatkan profesionalisme guru melalui bentuk pembelajaran inovatif seperti pembelajaran berbasis e-learning. Implementasi digital literacy lebih mendalam dapat dilakukan dengan memberikan siswa tugas-tugas authentic yang disertai dengan penilaian authenticnya. Sebagai salah satu integral dari IPA, biologi merupakan cabang ilmu yang memfokuskan objek pengamatannya pada gejala-gejala mahluk hidup. Umumnya, dalam pembelajaran biologi digunakan penugasan dan penilaian secara konvensional yaitu paper and pencil test sehingga menyebabkan pembelajaran menjadi monoton dan dominan bersifat hapalan.Salah satu cara alternatif untuk memadukan komponen penilaian authentic, pembelajaran dan pemanfaatan digital literacy yaitu dengan mengimplementasikan penilaian authentic berbasis e-learning dalam pembelajaran biologi artikel ilmiah ini ditujukan untuk menganalisis: 1) jenis jenis authentic assessment di dalam pembelajaran biologi, 2) integrasi authentic assessment berbasis e-learning untuk mendukung proses pembelajaran biologi.
\end{abstract}

Kata Kunci :Digital Literacy, Authentic Assessment, dan E-learning

\section{ABSTRACT}

Digital literacy occupies the latest issue in the education system of the 21st century. Global competition causes each student must be able to manage and find of well information resources. Digital literacy itself is defined as the competence used by learners to participate fully in the learning process by involving knowledge, skills and attitudes that are effective in the utilization of digital devices. Furthermore, Unesco (2017) defines digital literacy as a life skill to support lifelong education, cross national curriculum, enhances learner participation, and enhances teacher professionalism through innovative learning such as e-learning. The deeper implementation of digital literacy can be done by giving students authentic tasks accompanied by their authentic judgments. As one of the integrals of science, biology is a branch of science that focuses the object of observation on the phenomena of living things. Generally, in biology learning process used conventional assignment and paper and pencil test assessment so the learning becomes monotonic and support rote learning. One alternative way to integrate the authentic assessment component, learning and it utilization of digital literacy is to implement e-learning with authentic assessment in biology learning process. This scientific article is intended to analyze: 1) types of authentic assessment types 
in biology learning, 2) integration of e-learning based authentic assessment to support the biology learning process.

Key Words : Digital Literacy, Authentic Assessment, and E-learning

\section{PENDAHULUAN}

Digital literacy menempati isu terkini dalam sistem pendidikan di abad 21. Persaingan global mengakibatkan setiap siswa harus mampu mengelola dan mencari sumber informasi dengan baik. Karena kini setiap siswa memiliki akses informasi yang beragam baik secara tradisional maupun modern. Secara tradisional siswa dapat mengakses materi belajar melalui buku, ensiklopedia, dan bahkan surat kabar. Sebaliknya secara modern siswa dapat mengakses materi pembelajaran secara offline dan online. Melalui pemanfaatan secara offline siswa dapat mengakses materi melalui sumber belajar seperti encharta, ebook, gambar, dan video dalam bentuk digital. Sebaliknya, secara online siswa dapat mengakses materi baik melalui web-based learning yaitu schoology, google classroom, edmodo, dan moodle maupun melalui media sosial seperti faceboook, twitter, instagram, dan path. Kedua sumber belajar ini sangat penting untuk mengembangkan kompetensi siswa. Survey yang dilaksanakan oleh Comscore Inc. pada tahun 2011 menunjukkan pesatnya pertumbuhan penggunaan internet berusia muda di Indonesia sebanyak $40 \%$ berusia 15-24 tahun, berbeda dengan Hongkong dan Singapura total pengguna internet yang berusia 15-24 tahun hanya sekitar 20\% (Prawiradilaga, dkk, 2013). Data ini menunjukkan bahwa Indonesia memiliki potensi yang tinggi dalam pengembangan digital literacy siswanya.

Digital literacy sendiri diartikan sebagai kompetensi yang digunakan oleh peserta didik untuk berpartisipasi secara penuh dalam proses belajar dengan melibatkan pengetahuan, keterampilan, dan sikap yang efektif di dalam pemanfaatan perangkat digital. Lebih lanjut, Unesco(2017) menetapkan digital literacy sebagai salah satu life skill mendukung pendidikan sepanjang hayat, cross national curriculum, meningkatkan partisipasi pebelajar, dan meningkatkan profesionalisme guru melalui bentuk pembelajaran inovatif seperti pembelajaran berbasis e-learning. Namun masih terdapat kendala-kendala yang dalam implementasi digital literacy di masing-masing satuan pembelajaran khususnya di Indonesia yaitu tidak tersedianya perangkat digital, aksesibilitas jaringan internet yang masing kurang, serta isu seputar plagiarism karya siswa. Isu plagiarisme karya siswa menjadi fenomena baru ketika siswa telah menguasai digital literacy. Karena hampir sebagian besar siswa merupakan digital immigrant yang sulit untuk menggunakan IT secara baik untuk menunjang proses belajar (Samanhudi, 2017). Dengan demikian peran guru tidak lagi menjadi pusat pembelajaran akan tetapi sebagai lebih dominan berperan sebagai fasilitator dan 'rekan' di dalam proses pembelajaran.

Implementasi digital literacy lebih mendalam dapat dilakukan dengan memberikan siswa tugas-tugas authentic yang disertai dengan penilaian authenticnya. Asesmen authentic mengandung makna bahwa bagaimana suatu instrumen penilaian dapat mengukur kemampuan siswa secara menyeluruh setelah menyelesaikan tugas atau proses belajarnya. Lebih lanjut Mueller (2005) 
menyatakan bahwa asesmen authentic merupakan penilaian yang memberikan siswa pengalaman untuk mengerjakan realworld problem dan menerapkan konsep atau keterampilan esensial yang bermakna. Jenis penilaian tersebut akan mengukur domain afektif, psikomotor dan afektif siswa secara utuh. Adapun jenis-jenis penilaian authentic tersebut antara lain penilaian kinerja, penilaian peta konsep, penilaian peta pikiran, penilaian berbasis proyek, penilaian berpikir kritis dan penilaian berpikir kreatif. Jenis jenis penilaian authentic tersebut sangat cocok apabila dikombinasikan dengan pembelajaran berbasis e-learning, karena akan memiliki nurturant effect yaitu meningkatkan digital literacy siswa.

Sebagai salah satu integral dari IPA, biologi merupakan cabang ilmu yang memfokuskan objek pengamatannya pada gejala-gejala mahluk hidup. Umumnya, dalam pembelajaran biologi digunakan penugasan dan penilaian secara konvensional yaitu paper and pencil test sehingga menyebabkan pembelajaran menjadi monoton dan dominan bersifat hapalan. Fakta lain yaitu meskipun pembelajarannya telah menggunakan media asli dan materi kontekstual, namun penilaiannya masih bersifat konvensional. Sehingga terjadi kesenjangan antara model pembelajaran yang diimplementasikan dengan jenis penilaiannya. Proses belajar yang demikian sulit umtuk mengukur kemampuan berpikir tingkat tinggi dan kemampuan siswa secara menyeluruh. Salah satu cara alternatif untuk memadukan komponen penilaian authentic, pembelajaran dan pemanfaatan digital literacy yaitu dengan mengimplementasikan penilaian authentic berbasis e-learning dalam pembelajaran biologi.

Berdasarkan uraian tersebut maka artikel ilmiah ini ditujukan untuk menganalisis: 1) Jenis jenis assessment authentic di dalam pembelajaran biologi, 2) Integrasi assessment authentic berbasis $e$ learning untuk mendukung proses pembelajaran biologi.

\section{PEMBAHASAN}

Jenis Jenis Assessment Authentic di dalam Pembelajaran Biologi,

Asesmen merupakan hal integral dari proses pembelajaran, sehingga kegiatan asesmen harus dilakukan sepanjang rentang waktu proses pembelajaran. Asesmen adalah proses mengumpulkan informasi dan membuat keputusan berdasarkan informasi. Terdapat berbagai jenis penilaian authentic yang dapat digunakan untuk menunjang proses pembelajaran abad 21 beberapa diantaranya adalah rubrik penilaian berbasis proyek, rubrik penilaian peta konsep, rubrik penilaian kinerja, dan rubrik berpikir kritis siswa.

\section{a) Rubrik Penilaian Berbasis Proyek}

Tabel 01. Rubrik Penilaian Proses Pembelajaran Berbasis Proyek

\begin{tabular}{llll}
\hline Aspek & Kriteria & Skor \\
\hline 1. Pemilihan topik & Topik orisinal, kontekstual, dan sesuai dengan & 4 \\
& materi yang ada & & \\
& $\begin{array}{l}\text { Topik kurang orisinal, kontekstual dan sesuai } 3 \\
\text { dengan materi yang ada } \\
\end{array}$ & Topik kurang orisinal, kurang kontekstual dan 2 \\
\hline
\end{tabular}




\begin{tabular}{|c|c|c|}
\hline & $\begin{array}{l}\text { sesuai dengan materi yang ada } \\
\text { - Topik kurang orisinal, kurang kontekstual dan } \\
\text { kurang sesuai dengan materi yang ada }\end{array}$ & 1 \\
\hline \begin{tabular}{ll} 
2.Pembuatan & \multicolumn{2}{c}{ map/diagram } \\
terhadap topik & yang akan \\
diinvestigasi &
\end{tabular} & $\begin{array}{l}\text { - Ide/gagasan dalam menentukan hubungan sebab } \\
\text { akibat mengenai hal yang diamati adalah kompleks, } \\
\text { di luar materi yang diajarkan, dan memungkinkan } \\
\text { memperoleh penemuan baru. } \\
\text { - Ide/gagasan dalam menentukan hubungan sebab } \\
\text { akibat mengenai hal yang diamati adalah } \\
\text { sederhana, di luar materi yang diajarkan, dan } \\
\text { memungkinkan memperoleh penemuan baru. } \\
\text { - Ide/gagasan dalam menentukan hubungan sebab } \\
\text { akibat mengenai hal yang diamati adalah } \\
\text { sederhana, pada materi yang diajarkan, dan } \\
\text { memungkinkan memperoleh penemuan baru } \\
\text { - Ide/gagasan dalam menentukan hubungan sebab } \\
\text { akibat mengenai hal yang diamati adalah } \\
\text { sederhana, pada materi yang diajarkan, dan tidak } \\
\text { memungkinkan memperoleh penemuan baru }\end{array}$ & 4 \\
\hline $\begin{array}{l}\text { 3.Pembuatan rincian terhadap } \\
\text { tahapan proses }\end{array}$ & $\begin{array}{l}\text { - Kerangka proposal lengkap, berurutan dan } \\
\text { mengacu pada strategi proyek } \\
\text { - Kerangka proposal kurang lengkap, tetapi telah } \\
\text { berurutan dan mengacu pada strategi proyek } \\
\text { - Kerangka proposal kurang lengkap, kurang } \\
\text { berurutan dan mengacu pada strategi proyek } \\
\text { - Kerangka proposal kurang lengkap, kurang } \\
\text { berurutan dan kurang mengacu pada strategi } \\
\text { proyek }\end{array}$ & 1 \\
\hline 4.Monitoring kerja proyek & $\begin{array}{l}\text { - Jadwal kerja jelas, lembar kemajuan siswa jelas, } \\
\text { dan sesuai dengan masing-masing tahapan proyek } \\
\text { - Jadwal kerja kurang jelas, lembar kemajuan siswa } \\
\text { jelas, dan sesuai dengan masing-masing tahapan } \\
\text { proyek. } \\
\text { - Jadwal kerja kurang jelas, lembar kemajuan siswa } \\
\text { kurang jelas, dan sesuai dengan masing-masing } \\
\text { tahapan proyek } \\
\text { - Jadwal kerja kurang jelas, lembar kemajuan siswa } \\
\text { kurang jelas, dan kurang sesuai dengan masing- } \\
\text { masing tahapan proyek }\end{array}$ & 4 \\
\hline
\end{tabular}

Tabel 02.Rubrik Penilaian Produk Akhir Pembelajaran Berbasis Proyek

\begin{tabular}{llll}
\hline Aspek & Kriteria & Skor \\
\hline 1. Format Laporan & $\bullet$ & $\begin{array}{l}\text { Laporan lengkap, sistematis, rapi dan sesuai dengan kaidah } \\
\text { bahasa. }\end{array}$ & 4 \\
& - & $\begin{array}{l}\text { Laporan kurang lengkap, sistematis, rapi dan telah sesuai } \\
\text { dengan kaidah bahasa }\end{array}$ & 3 \\
& $-\quad \begin{array}{l}\text { Laporan kurang lengkap, kurang sistematis, tetapi rapi dan } \\
\text { sesuai dengan kaidah bahasa. }\end{array}$ & 2 \\
& $-\quad \begin{array}{l}\text { Laporan kurang lengkap, kurang sistematis, kurang rapi dan } \\
\text { tetapi sesuai sesuai dengan kaidah bahasa }\end{array}$ & 1 \\
\hline 2. Deskripsi Temuan & $-\begin{array}{l}\text { Data yang dideskripsi lengkap analisis data teliti, dan sesuai } \\
\text { dengan yang diperlukan }\end{array}$ & 4 \\
\hline
\end{tabular}




\begin{tabular}{|c|c|}
\hline & $\begin{array}{l}\text { Data yang dideskripsi kurang lengkap, tetapi sudah ada } \\
\text { analisis data yang teliti, dan sesuai dengan yang diperlukan } \\
\text { - Data yang dideskripsi kurang lengkap, analisis data kurang } \\
\text { teliti, tetapi telah sesuai dengan yang diperlukan } \\
\text { - Data yang dideskripsi kurang lengkap, analisis data kurang } \\
\text { teliti, dan kurang sesuai dengan yang diperlukan }\end{array}$ \\
\hline 3. Pembahasan & $\begin{array}{l}\text { - Paparan pembahasan komperehensif, mendalam, dan sesuai } \\
\text { dengan teori. } \\
\text { - Paparan pembahasan kurang komperehensif, tetapi telah } \\
\text { mendalam, dan sesuai dengan teori } \\
\text { - Paparan pembahasan kurang komprehensif, kurang } \\
\text { mendalam, tetapi telah sesuai dengan materi } \\
\text { - Paparan pembahasan kurang komprehensif, kurang } \\
\text { mendalam, dan kurang sesuai dengan teori. }\end{array}$ \\
\hline 4.Simpulan & $\begin{array}{l}\text { - Lengkap, sesuai dengan tujuan, dan sesuai dengan } \\
\text { data/fakta/bukti yang diamati } \\
\text { - Kurang lengkap, tetapi sesuai dengan tujuan dan sesuai } \\
\text { dengan data/fakta/bukti yang diamati } \\
\text { - Kurang lengkap, kurang sesuai dengan tujuan, dan namun } \\
\text { sesuai dengan data/fakta/bukti yang diamati. } \\
\text { - Kurang lengkap, kurang sesuai dengan tujuan, dan kurang } \\
\text { sesuai dengan data/fakta/bukti yang diamati. }\end{array}$ \\
\hline
\end{tabular}

b) Rubrik Peta Konsep

Tabel 03. Rubrik Penilaian Peta Konsep:

\begin{tabular}{|c|c|c|c|}
\hline No & Kriteria Penilaian & Skor & Skor Total \\
\hline \multirow[t]{6}{*}{1} & Kata-kata konsep sesuai dengan topik & & \\
\hline & - 81-100\% benar & 5 & \\
\hline & - $61-80 \%$ benar & 4 & \\
\hline & - $41-60 \%$ benar & 3 & \\
\hline & - 21-40\% benar & 2 & \\
\hline & $-0-20 \%$ benar & 1 & \\
\hline \multirow[t]{6}{*}{2} & Kata-kata konsep disusun sesuai dengan hirarki & & \\
\hline & - 81-100\% benar & 5 & \\
\hline & - $61-80 \%$ benar & 4 & \\
\hline & $-41-60 \%$ benar & 3 & \\
\hline & - 21-40\% benar & 2 & \\
\hline & $-0-20 \%$ benar & 1 & \\
\hline \multirow[t]{6}{*}{3} & Kata-kata penghubung/proposisi antar konsep sesuai & & \\
\hline & - 80-100\% benar & 5 & \\
\hline & - $60-80 \%$ benar & 4 & \\
\hline & - $40-60 \%$ benar & 3 & \\
\hline & - $20-40 \%$ benar & 2 & \\
\hline & $-0-10 \%$ benar & 1 & \\
\hline \multirow[t]{6}{*}{4} & Terdapat sejumlah tingkatan yang sesuai dengan hirarki. & & \\
\hline & - terdapat satu tingkatan & 5 & \\
\hline & - terdapat dua tingkatan & 10 & \\
\hline & - terdapat tiga tingkatan & 15 & \\
\hline & - terdapat empat tingkatan & 20 & \\
\hline & - terdapat lima tingkatan & 25 & \\
\hline
\end{tabular}




\begin{tabular}{lll}
\hline 5 & Terdapat hubungan silang antar konsep yang terbentuk. & \\
\hline - terdapat satu hubungan silang & 5 \\
- terdapat dua hubungan silang & 10 \\
- terdapat tiga hubungan silang & 15 \\
- terdapat empat hubungan silang & 20 \\
- terdapat lima hubungan silang & 25 \\
\hline
\end{tabular}

Total

c) Rubrik Penilaian Kinerja

Tabel 04. Rubrik Penilaian Kinerja

\begin{tabular}{|c|c|c|c|c|}
\hline \multirow[t]{2}{*}{$\mathbf{N}$} & \multirow{2}{*}{$\begin{array}{l}\text { Kemampuan } \\
\text { Dasar }\end{array}$} & \multirow[t]{2}{*}{ Indikator } & \multirow[t]{2}{*}{ Kriteria penilaian } & Skor \\
\hline & & & & $\begin{array}{llll}4 & 3 & 2 & 1\end{array}$ \\
\hline \multirow[t]{2}{*}{1.} & $\begin{array}{l}\text { Merencanakan } \\
\text { penelitian }\end{array}$ & $\begin{array}{l}\text { Menentukan } \\
\text { alat dan bahan }\end{array}$ & $\begin{array}{l}\text { - Relevan dengan data yang dicari } \\
\text { - Efisien dengan dana, waktu dan tenaga } \\
\text { - Memilih alat ukur yang sesuai } \\
\text { - Konsisten dalam pengulangan }\end{array}$ & \\
\hline & & $\begin{array}{l}\text { Merancang } \\
\text { prosedur kerja } \\
\text { penelitian }\end{array}$ & $\begin{array}{l}\text { - langkah sistematis } \\
\text { - dapat dikerjakan dengan mudah } \\
\text { - dapat dikerjakan dengan aman } \\
\text { - dapat mencapai tujuan }\end{array}$ & \\
\hline \multirow[t]{3}{*}{2.} & $\begin{array}{l}\text { Kegiatan } \\
\text { praktikum }\end{array}$ & $\begin{array}{l}\text { Melakukan } \\
\text { pengamatan }\end{array}$ & $\begin{array}{l}\text { - } \text { Pengamatan dilakukan dengan } \\
\text { menggunakan seluruh indera yang sesuai } \\
\text { - Mengidentifikasi perubahan-perubahan } \\
\text { dalam objek yang diamati } \\
\text { - Akurat di dalam melakukan pengukuran } \\
\text { - Terampil }\end{array}$ & \\
\hline & & $\begin{array}{l}\text { sikap dalam } \\
\text { melakukan } \\
\text { pengamatan }\end{array}$ & $\begin{array}{l}\text { - Antusias } \\
\text { - Percaya diri } \\
\text { - Tekun dan serius } \\
\text { - Memiliki rasa ingin tahu yang tinggi }\end{array}$ & \\
\hline & & $\begin{array}{l}\text { Mengumpulka } \\
\mathrm{n} \text { dan } \\
\text { mengolah data }\end{array}$ & $\begin{array}{l}\text { - Data relevan dengan tujuan dan variabel } \\
\text { penelitian } \\
\text { - Dasar pengelompokannya jelas } \\
\text { - Jumlah data sesuai keperluan } \\
\text { - Deskripsi data detail }\end{array}$ & \\
\hline 3. & Penutup & $\begin{array}{l}\text { Membersihkan } \\
\text { alat dan bahan }\end{array}$ & $\begin{array}{l}\text { - Inisiatif diri sendiri } \\
\text { - Rapi } \\
\text { - Mengembalikan alat dan bahan ke } \\
\text { tempat semula } \\
\text { - Membersihkan alat sesuai dengan } \\
\text { karakteristik bahan }\end{array}$ & \\
\hline
\end{tabular}

\section{d) Rubrik Penilaian Berpikir Kritis}

Tabel 05.Rubrik Penilaian Berpikir Kritis Siswa

Indikator Skor Karakteristik/Deskriptor

\begin{tabular}{cccc}
\hline $\mathbf{( 1 )}$ & $(\mathbf{2})$ & $\mathbf{( 3 )}$ \\
\hline Merumuskan & 4 & $\bullet$ & Rumusan masalah sesuai dengan narasi permasalahan \\
\hline
\end{tabular}




\begin{tabular}{|c|c|c|}
\hline \multirow[t]{5}{*}{ masalah } & & $\begin{array}{l}\text { - Dirumuskan dalam bentuk pertanyaan yang memberikan arah } \\
\text { untuk menemukan jawaban/solusi } \\
\text { - Menunjukkan adanya variabel bebas dan variabel terikat } \\
\text { - Bahasan yang logis dan bahasa yang baik dan benar }\end{array}$ \\
\hline & 3 & $\begin{array}{l}\text { - Rumusan masalah sesuai dengan narasi permasalahan } \\
\text { - Menunjukkan adanya variabel bebas dan variabel terikat } \\
\text { - Bahasan yang logis dan bahasa yang baik dan benar }\end{array}$ \\
\hline & 2 & $\begin{array}{l}\text { - Rumusan masalah sesuai dengan narasi permasalahan } \\
\text { - Bahasan yang logis dan bahasa yang baik dan benar }\end{array}$ \\
\hline & 1 & $\begin{array}{l}\text { - Rumusan masalah sesuai dengan narasi permasalahan } \\
\text { - Bahasa tidak baik dan tidak benar }\end{array}$ \\
\hline & 0 & - Tidak merumuskan masalah \\
\hline \multirow[t]{5}{*}{$\begin{array}{l}\text { Memberikan } \\
\text { argumen }\end{array}$} & 4 & $\begin{array}{l}\text { - Argumen dengan alasan yang sesuai } \\
\text { - Mengemukakan fakta yang terdapat dalam paragraf } \\
\text { - Dikemukakan dengan argumen yang utuh } \\
\text { - Bahasan yang logis dan menunjukkan jalan pikiran yang runut }\end{array}$ \\
\hline & 3 & $\begin{array}{l}\text { - Argumen dengan alasan yang sesuai } \\
\text { - Mengemukakan fakta yang terdapat dalam paragraf } \\
\text { - Dikemukakan dengan argumen yang tidak utuh } \\
\text { - Bahasan yang logis dan menunjukkan jalan pikiran yang runut }\end{array}$ \\
\hline & 2 & $\begin{array}{l}\text { - Mengemukakan fakta yang terdapat dalam paragraf } \\
\text { - Bahasan yang logis dan menunjukkan jalan pikiran yang runut }\end{array}$ \\
\hline & 1 & $\begin{array}{l}\text { - Mengemukakan fakta yang terdapat dalam paragraf } \\
\text { - Bahasan tidak logis dan tidak menunjukkan jalan pikiran yang } \\
\text { runut }\end{array}$ \\
\hline & 0 & - Tidak memberikan argumen \\
\hline \multirow[t]{5}{*}{$\begin{array}{l}\text { Melakukan } \\
\text { deduksi }\end{array}$} & 4 & $\begin{array}{l}\text { - Memberikan deduksi yang logis } \\
\text { - Mengaitkan analisis yang diberikan dengan teori } \\
\text { - Analisis dirumuskan dalam bahasan yang runut dan bahasa yang } \\
\text { baik dan benar }\end{array}$ \\
\hline & 3 & $\begin{array}{l}\text { - Memberikan deduksi yang logis } \\
\text { - Analisis dirumuskan dalam bahasan yang runut dan bahasa yang } \\
\text { baik dan benar }\end{array}$ \\
\hline & 2 & $\begin{array}{l}\text { - Memberikan deduksi yang kurang logis } \\
\text { - Ada sedikit teori } \\
\text { - Analisis dirumuskan dalam bahasan yang runut dan bahasa yang } \\
\text { baik dan benar }\end{array}$ \\
\hline & 1 & $\begin{array}{l}\text { - Memberikan deduksi yang kurang logis } \\
\text { - Analisis dirumuskan dalam bahasan yang kurang runut dan } \\
\text { bahasa yang tidak baik }\end{array}$ \\
\hline & 0 & - Tidak melakukan deduksi \\
\hline $\begin{array}{l}\text { Melakukan } \\
\text { Induksi }\end{array}$ & 4 & $\begin{array}{l}\text { - Jawaban benar sesuai dengan teori dan fakta } \\
\text { - Ditambahkan dengan fakta pendukung jawaban yang tidak } \\
\text { terdapat dalam paragraf } \\
\text { - Bahasan menunjukkan jalan pikiran yang logis dan runut, serta } \\
\text { bahasa yang digunakan baik dan benar }\end{array}$ \\
\hline
\end{tabular}




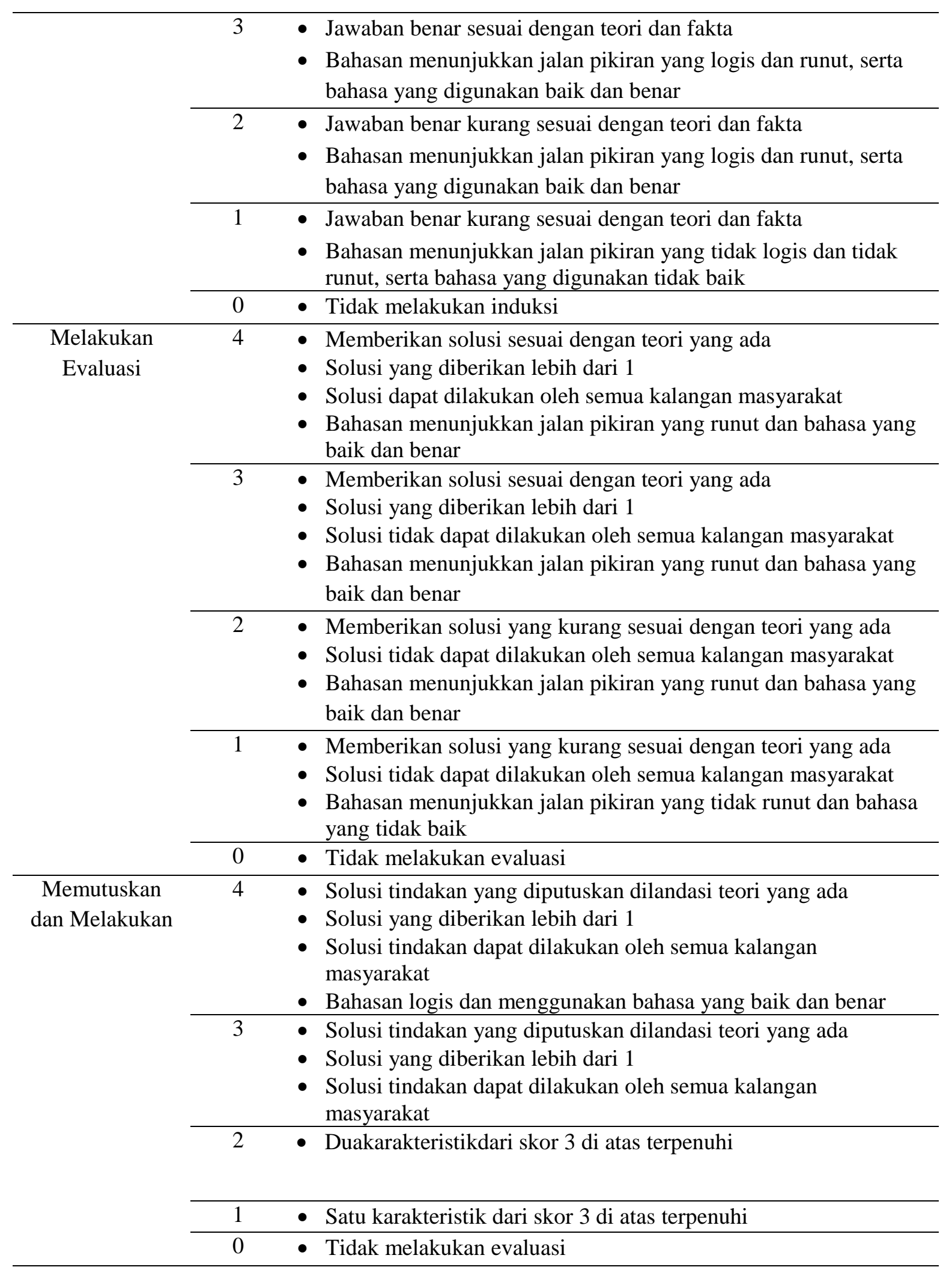

Nilai $=\frac{\text { skor yang diperoleh }}{\text { skormaksimum }} \times 100$ 


\section{Integrasi Authentic Assessment Berbasis E-learning untuk Mendukung Proses Pembelajaran Biologi.}

Asesmen autentik $r r$ dapat
didefinisikan sebagai suatu bentuk
penilaian yang mengukur kinerja
dalam suatu tugas kehidupan nyata, situasi yang relevan, atau masalah-masalah yang bermanfaat, bermakna, dan berarti. Jadi asesmen autentik digunakan mengukur kemampuan siswa yang sesngguhnya, yang mencakup aspek-aspek yang luas dalam kehidupan keseharian siswa. Untuk melakukan asesmen autentik diperlukan tugas-tugas autentik (authentic task) yang harus dikerjakan. Sedangkan asesmen alternatif secara sederhana diartikan sebagai pemanfaatan pendekatan nontradisional untuk memberi penilaian kinerja atau hasil belajar kepada siswa. Atau penilaian yang tidak melibatkan suatu tes baku dengan butir-butir tes tradisional. Asesmen alternatif sangat terbuka dengan berbagai metode yang inovatif dalam evaluasi, sangat berbeda dengan tipe-tipe standardized test (Warpala, 2006).

Dalam kaitannya dengan pembelajaran berbasis e-learning integrasi tugas pembelajaran dapat menggunakan

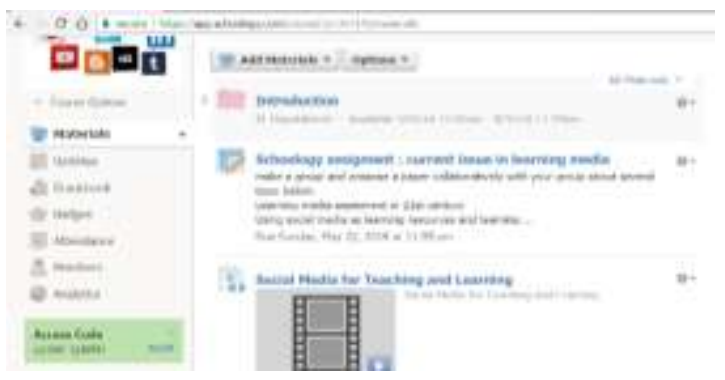

berbagai web-based learning seperti schoology, google classroom, edmodo, dan moodle. Masing-masing web based learning tersebut memiliki fitur yang hampir serupa sehingga guru dapat memberikan penugasan autentik melalui web tersebut. Misalnya saja schoology yang menyediakan fitur assignment bagi para guru atau dosen untuk memberikan tugas tertentu dalam interval waktu tertentu. Fitur ini sangat bermanfaat bagi guru untuk memanajemen tugas siswa dengan baik. Siswa yang terlambat mengumpulkan tugas akan diberi notifikasi late, sedangkan siswa yang tepat waktu mengumpulkan tugas akan diberi keterangan on time oleh sistem. Berikut merupakan tampilan fitur assignment yang disediakan oleh schoology dalam mata kuliah evaluasi pembelajaran.

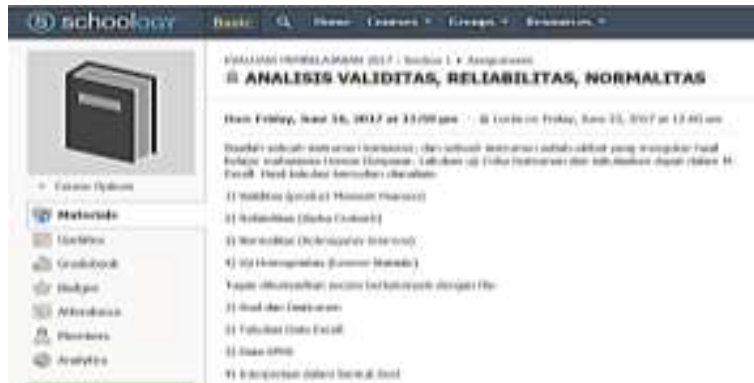

Gambar 01. Fitur assignment pada schoology

Tindak lanjut dari penugasan pada fitur assignment ini adalah dengan memasukkan rubrik penilaian tugas pada fitur material. Siswa berhak mengetahui rubrik penilaian yang diberikan oleh gurunya. Dengan mengetahui rubrik kriteria penilaian siswa akan lebih terfokus di dalam memenuhi aspek aspek pembelajaran yang diberikan oleh guru. Guru dapat secara langsung melakukan upload rubrik penilaian pada fitur material ini. Berikut merupakan gambar fitur material pada schoology.

Gambar 02. Fitur Material pada Schoology

Hal yang serupa juga ditemukan pada web-based learning yaitu edmodo. Edmodo menyediakan fitur post untuk penugasan, informasi seputar mata kuliah atau mata pelajaran, polling dan snapshot. Gambar 03 dan Gambar 04 menjelaskan bagaimana cara untuk mengupload tugas dan rubrik penilaian di web edmodo. 
Gambar 03. Proses Penugasan Pada

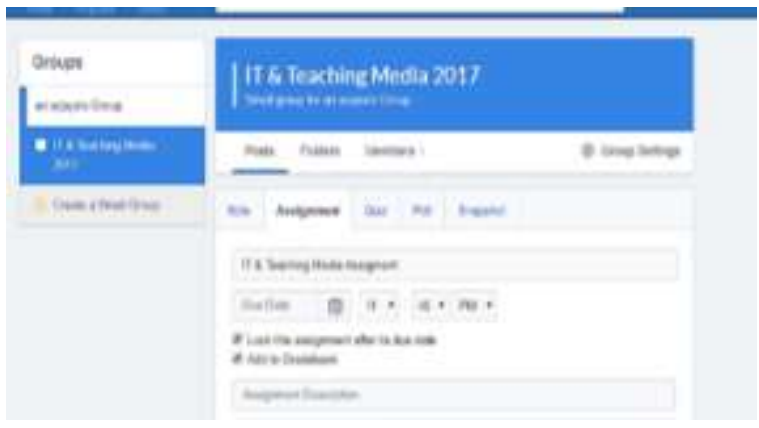

WebsiteEdmodo

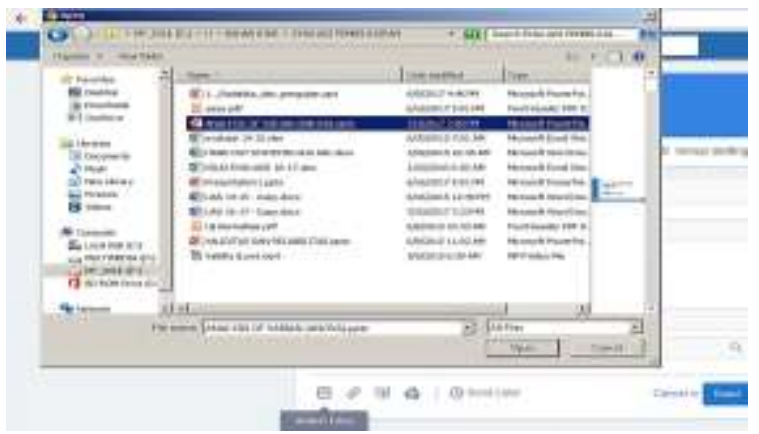

Gambar 04.Attachment Rubrik pada Pada WebsiteEdmodo

Fitur assignment atau penugasan di edmodo memiliki persamaan dengan fitur assignment yang dimiliki oleh schoology. Perbedaan kedua jenis web-based learning ini terletak pada tujuan yang ingin dicapai untuk pembelajaran. Pembelajaran berbasisedmodolebih menekankan pada eksplorasi materi baik untuk penugasan maupun sebagai sumber belajar, dan sebaliknya pada schoologylebih menekankan pada managemen guru untuk mengelola pembelajaran siswa, tidak hanya materi pembelajaran, tetapi juga dokumentasi pembelajaran, dan administrasi dalam pembelajaran.

Terdapat beberapa penelitian webbased learning yang mendukung pembelajaran berbasis e-learning. Penelitian Ramelan dkk. (2015) mengungkapkan bahwa penerapan social learning network berhasil di dalam meningkatkan hasil belajar siswa pada mata pelajaran pemrograman dasar jurusan teknik komputer dan informatika di SMKN 2 Bandung. Hasil yang serupa juga diperoleh oleh Apriyana dkk. (2015) yan menyatakan bahwa terdapat perbedaan yang signifikanantara siswa yang menggunakan portal elearning berbasis schoology dibandingkan dengan siswa yang tidak menggunakan portal elearning berbasis schoology terhadap hasil belajar IPS siswa. Disisi lain dengan platform yang berbeda Rahmi (2015) mengungkapkan bahwa penerapan Edmododalam pembelajaran PPKn pada kelas X TPHP A SMK Negeri 1 Bawendapat meningkatkan antusiasme, keterampilan, dan kemandirian siswa secara signifikan di dalam proses pembelajaran. Dengan demikian dapat disimpulkan bahwa pembelajaran webbased learning mampu mengembangkan aspek kognitif dan aspek afektif siswa di dalam proses pembelajaran.

\section{PENUTUP}

\section{Simpulan}

Adapun kesimpulan dalam artikel ilmiah ini dapat diuraikan sebagai berikut:

1) Terdapat berbagai jenis penilaian authentic yang dapat digunakan untuk menunjang proses pembelajaran e-learning beberapa diantaranya adalah rubrik penilaian berbasis proyek, rubrik penilaian peta konsep, rubrik penilaian kinerja, dan rubrik berpikir kritis siswa.

2) Secara umum fitur assignmentatau post dan fitur material sangat berperan penting di dalam pemberian tugas dan upload rubrik penilaian siswa dalam pembelajaran 
e-learning, khususnya web-based learning.

\section{Saran}

Adapun saran dalam artikel ilmiah ini dapat diuraikan sebagai berikut:

1) Selain integrasi materi dengan rubrik penilaian siswa, sehingga menarik untuk dikaji bagaimana efektifitas mobile based learning untuk mengembangkan berbagai aspek pembelajaran siswa.

2) Penilaian authenticassessment berbasis digital devices yaitu sangat penting untuk dikembangkan untuk memudahkan guru di dalam proses penilaian dan tabulasi data.

3) Sangat menarik untuk dikaji bagaimana pengembangan modul pembelajaran berbasis e-learning dapat mengembangkan kemampuan berpikir tingkat tinggi siswa yaitu keterampilan berpikir kritis, kreatif, problem solving dan metakognitif.

\section{DAFTAR PUSTAKA}

Apriyana, K.F., Nyoman W., Desak P. P.(2015).Pengembangan Portal $E$ learning Berbasis Schoology Pada Mata Pelajaran IPS Kelas VIII Di SMPN 1 Banjarangkan.e-Journal Edutech Universitas Pendidikan Ganesha. Vol: 3 No: 1 Tahun: 2015.

Mueller, J.(2005). The Authentic Assessment Toolbox: Enhancing Student Learning through Online Faculty Development. Journal of Online Learning and Teaching. Vol.1 No.1.
Prawiradilaga, D. S. dkk. (2013).Mozaik Teknologi Pendidikan: ELearning. Jakarta: Kencana Prenadamedia Group.

Rahmi, S.(2015) Penerapan Edmodo untuk Meningkatkan Sikap Kemandirian Belajar Siswa Pada Mata Pelajaran PPKnDI SMK Negeri 1 Bawen. Skripsi. Semarang: Universitas Negeri Semarang.

Ramelan, A. (2015).Penerapan Social Learning Network Berbasis Schoology Dalam Meningkatkan Hasil Belajar Siswa Pada Mata Pelajaran Pemrograman Dasar Jurusan Teknik Komputer dan Informatika di SMKN 2 Bandung. Bandung: Universitas Pendidikan Indonesia

Samanhudi, U.(2017).Ketika Semua Informasi Ada di Google, Masihkah Peran Guru Penting?.http://www.biem.co/read /2017/07/26/2733/udi-samanhudiketika-semua-informasi-ada-digoogle-masihkah-peran-gurupenting (diakses pada tanggal 27 Juli 2017)

Unesco.(2017).Digital literacy In Education.https://www.google.co $\mathrm{m} / \mathrm{url}$ ? sa $=\mathrm{t} \& \mathrm{rct}=\mathrm{j} \& \mathrm{q}=\& \mathrm{esrc}=\mathrm{s} \& \mathrm{so}$ urce $=$ web\&cd $=3 \&$ ved $=0$ ahUKEwj Bs7Kw1anVAhVDybwKHePeBY 0QFggyMAI\&url=http\%3A\%2F\% 2Funesdoc.unesco.org\%2Fimages \%2F0021\%2F002144\%2F 14485 e.pdf\&usg=AFQjCNHqw9HyDhI B09OAdHc xTbcV-jaDg. (diakses pada tanggal 27 Juli 2017)

Warpala, I. W. S. (2006). Penilaian Hasil Belajar (Asesmen Autentik). Makalah disampaikan pada Diklat Guru SD/MI Bidang IPA. Undiksha. 
